\title{
Pelecitus tercostatus (Molin, 1960) (Nematoda, Onchocercidae) in Amazona vinacea (Aves, Psittaciformes) from Argentina: morphological details and clinical findings
}

\author{
Julia I. Diaz ${ }^{*}$, Dante L. Di Nucci², Martín P. Falzone², Natalia M. Demergassi², \\ M. Fernanda Lois ${ }^{2}$, Raúl 0. Zalazar ${ }^{2}$, Graciela T. Navone ${ }^{1}$ and Gustavo G. Gachen ${ }^{2}$ \\ ${ }^{1}$ Centro de Estudios Parasitológicos y de Vectores (CCT La Plata-CONICET-UNLP), Calle 2 No. 584, 1900, La Plata, Buenos Aires Province, \\ Argentina. ${ }^{2}$ Fundación Temaikèn, Ruta 25 Km 0,700 Belén de Escobar, Buenos Aires Province, Argentina
}

\begin{abstract}
Pelecitus tercostatus (Molin, 1860) (Onchocercidae, Dirofilariinae) was found in the leg of a Vinaceous-breasted Parrot Amazona vinacea (Aves, Psittaciformes) from Misiones, Argentina. The present report enlarges the host distribution of the species and represents the first record of any nematode in A. vinacea. The macroscopic lesions produced in the bird are also described.
\end{abstract}

\section{Keywords}

Nematoda, Onchocercidae, Pelecitus tercostatus, Psittacidae, Amazona vinacea, Argentina

Species of the nematode genus Pelecitus Railliet et Henry, 1910 (Onchocercidae, Dirofilariinae) are parasites of at least 30 families of birds, with only 3 species known from mammals, and are widely distributed all over the world (Bartlett 1983; Bartlett and Greiner 1986; Jimenez-Ruiz et al. 2004). Adult worms occur in nodules on the leg and foot, and microfilariae inhabit the feathered skin (Bartlett and Greiner 1986; Bartlett 1992).

In many South American countries, knowledge of parasite biodiversity in Neotropical birds is poor and data is completely lacking for common species (Oniki et al. 2002). The Vinaceous breasted Parrot Amazona vinacea (Kuhl) (Aves: Psittaciformes) is an endangered species of psittacine (BirdLife International 2011) endemic in the Atlantic forest in southeastern South America, particularly in eastern Brazil, eastern Paraguay, and northern Argentina. The aim of this note is to report the first record of Pelecitus tercostatus (Molin, 1860) in an A. vinacea from Misiones, Argentina and to describe the macroscopic lesions produced by the nematode in the bird.

The bird was originally from San Pedro, Misiones $\left(26^{\circ} 37^{\prime} 18^{\prime \prime} \mathrm{S}, 54^{\circ} 6^{\prime} 35^{\prime \prime} \mathrm{W}\right)$, where it was confiscated by envi- ronmental authorities. It was sent to Foundation Temaikèn on 21 April 2006 to become part of a captive breeding program as part of The Paraná Pine Conservation Project. The animal was examined under anaesthesia during a routine check-up. The bird weighed $0.374 \mathrm{~kg}$ and was under good general condition. Initial physical examination revealed markedly bilateral swollen areas associated with the tibiotarsus-tarsometatarsal joint. There were numerous soft, swollen subcutaneous nodes in both legs (Fig. 1A). There were no signs of discomfort or dysfunction in relation to the masses. On palpation they appeared to be non-painful and there were no signs of swelling. These nodules were found as a clinical finding and no other problems were observed on physical or haematological examination.

Radiographic examination of the legs showed soft-tissue swelling around the mentioned joint with no evidence of bone involvement. Previous radiographic examinations displayed the same cyst structures, on its entrance into the Conservation Project.

A small-gauge-needle aspirate from one of the nodes was performed, obtaining an amber odourless gelatinous liquid. Its microscopic examination revealed a large number 
of red blood cells and the sample was negative for microfilariae.

After 40 days with no evidence of clinical signs, the bird died of head trauma in the Biopark of the Foundation Temaikèn in Belén de Escobar, Buenos Aires, Argentina, on 21 November 2010.

The necropsy report showed eight round masses on its right leg and seven on its left leg. On their opening, a large number of adult nematode parasites were found (Fig. 1B). About 110 worms were extracted from the right leg, and about 90 from the left leg.

Nematodes were removed from the nodes, fixed in $10 \%$ formalin, and stored in $70 \%$ ethanol. Ten males and ten fe- males were cleared in glycerin for light microscope study. Two males and 2 females were dried using the critical point method, and examined by SEM (Jeol JSV 6063 LV $^{\circledR}$ ). Morphological descriptions follow the terminology given by Bartlett and Greiner (1986). Voucher specimens were deposited in the Helminthological Collection of the Museo de La Plata (CHMLP), La Plata, Argentina ( $\mathrm{N}^{\circ}$ 6504). Measurements are given in micrometers, unless otherwise stated.

Male and female morphometrics are presented in Table I (Figs 1, 2). Cuticle thick, transversally striated. Symmetry of lateral alae showing sexual dimorphism. On apical view, 4 inner-labial and 4 outer-cephalic papillae form a square; the amphids are not salient (Figs 1C, 2B, D). The oesophagus is
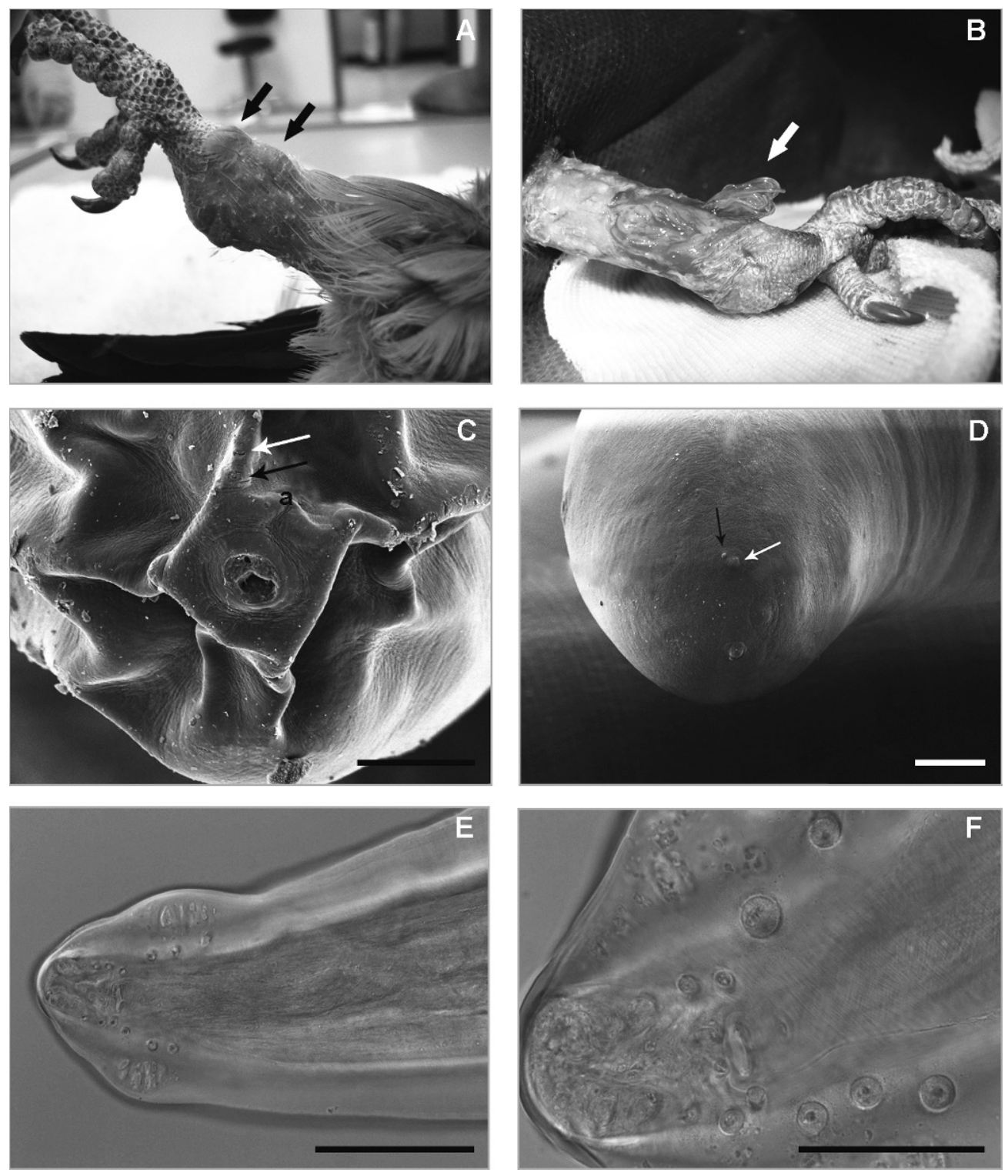

Fig. 1. A. Leg of Amazona vinacea showing nodes. B. Adult nematodes in an opened node. C. Adults of Pelecitus tercostatus, apical view, showing cephalic papillae arrangement (see arrows) and amphids (a). D. Posterior end of female showing the anal papillae (white arrow), and phasmids (black arrow). E-F. Male, posterior end showing papillae arrangement. Scale bars (in micrometers): $\mathrm{C}$ and $\mathrm{D}=20, \mathrm{E}=50, \mathrm{~F}=100$ 
Table I. Measurements of Pelecitus tercostatus from Amazona vinacea

\begin{tabular}{lccc}
\hline Females $(\mathrm{n}=10)$ & Mean & Min. & Max. \\
\hline Total length $(\mathrm{mm})$ & 26.6 & 24.9 & 27.8 \\
Width at vulva level & 417 & 370 & 450 \\
Maximum width & 742 & 600 & 850 \\
Oesophagus & 1020 & 900 & 1100 \\
Vulva (dae) & 762 & 550 & 970 \\
Nerve ring & 189 & 170 & 230 \\
Tail & 97 & 90 & 110 \\
Males $(\mathrm{n}=10)$ & & & \\
Total length $(\mathrm{mm})$ & 11.1 & 8.6 & 12.7 \\
Maximum width & 459 & 400 & 500 \\
Oesophagus & 863 & 800 & 950 \\
Excretory pore $(\mathrm{n}=2)$ & - & 105 & 250 \\
Nerve ring & 161 & 150 & 175 \\
Tail & 62 & 58 & 65 \\
Right spicule & 82 & 75 & 90 \\
Left spicule & 129 & 120 & 145 \\
\hline
\end{tabular}

dae - distance from anterior end.

stout, cylindrical, clearly demarcated from intestine (Fig. 2A). Male presents a slight rotation in the later third of the body. Lateral alae asymmetrical, left larger than right. Caudal alae slightly asymmetrical. Caudal papillae distributed as follow: (1) a group of 3 pairs of pedunculate pre-cloacal papillae sometimes extending into alae, asymmetrical in arrangement; (2) 3 pairs of smaller, semipedunculate ad-cloacal papillae, middle one external, forming a triangle, near the group 4; (3) 3 pairs of small, sessile papillae in the caudal extremity, symmetrical or asymmetrically arrangement, (4) small, sessile peri-cloacal papillae, one pair anterior (or/and single papilla), one pair posterior to cloaca, plus small papillae below them. Hyaline inclusions present within caudal alae (Figs 1E, F, 2G, $\mathrm{H})$. Spicules delicate, unequal, and dissimilar; left spicule larger than right and divided into a calomus more sclerotized than the lamina (Figs 2G, H).

Body of the female straight, not twisted or coiled. Postdeirids slightly visible. Lateral alae symmetrical. Vulva anterior to the oesophagic-intestinal junction (Fig. 2A). Caudal end rounded (Fig. 2E). Phasmids subterminal in position, opening dorso-lateral in a prominent papilla (Figs 1D, 2F). Microfilariae not observed.

Following the key to species of Pelecitus proposed by Bartlett and Greiner (1986) specimens from A. vinacea agree with $P$. tercostatus mainly by the size and because the body of gravid female is straight or curved but never twisted or coiled. The general morphology and measurements of present specimens agree with those given by other authors. In males the disposition and number of caudal papillae was variable. In some males 4 papillae were observed in the left side of group (1). Moreover, in group (4) the precloacal papilla can be single or double. These observations are in accordance with the intraspecific variation mentioned by
Bartlett and Greiner (1986) for P. tercostatus and other Pelecitus species. As was observed by previous authors (Bartlett and Greiner 1986) the males had asymmetrical lateral alae, the left ala being larger than the right, while female alae were symmetrical.

Other Pelecitus species reported in Psittacidae are Pelecitus helicinus (Molin, 1860), Pelecitus circularis (Molin, 1860), Pelecitus andersoni Bartlett et Greiner, 1986 (Bartlett and Greiner 1986), and Pelecitus sp. (Allen et al. 1985; Greiner and Ritchie 1994). However, their features do not agree with the present specimens, especially in the morphology of the posterior ends of males and females and morphology of the spiculae. In P. tercostatus spiculae are delicate, unequal, dissimilar, and tip tapered, being the left larger than the right (mean 129 vs 82 , respectively), in contrast in $P$. helicinus they are stout, subequal, shorter (i.e. around 75), and tip truncated, whereas in P. circularis and P. andersoni spiculae are unequal, dissimilar, stout, and tip truncated (Bartlett and Greiner 1986; Vicente et al. 1995).

Pelecitus tercostatus has been reported previously only in members of Psittaciformes from the Neotropical region such as the Turquoise-fronted Parrot Amazona aestiva (L.), the Alder Parrot Amazona tucumana (Cabanis), and the Scalyheaded Parrot Pionus maximiliani (Kuhl) (Greve et al. 1982; Bartlett and Greiner 1986). In Argentina, P. tercostatus has been previously recovered only from $P$. maximiliani from San Antonio, Misiones (Schuurmans Sterkhoven 1951). The only other species recorded from Argentina is Pelecitus fulicatreae (Diesing, 1861) from Podiceps occipitalis (Garnot) (Podicipediformes) from Chubut Province (Escudero et al. 2007).

The wide distribution of the genus in birds is related to its transmission using lice, mosquitoes and other arthropods as 


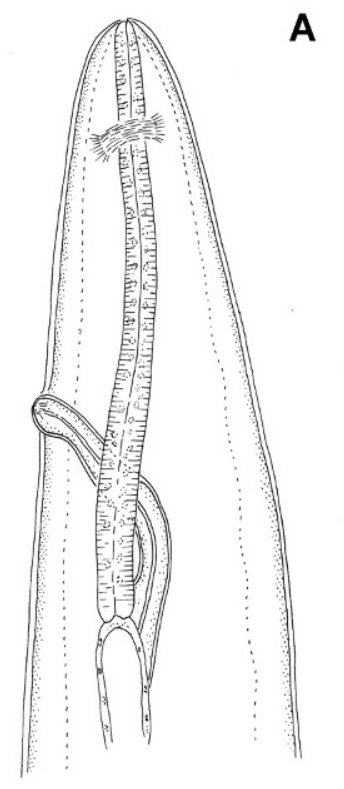

F

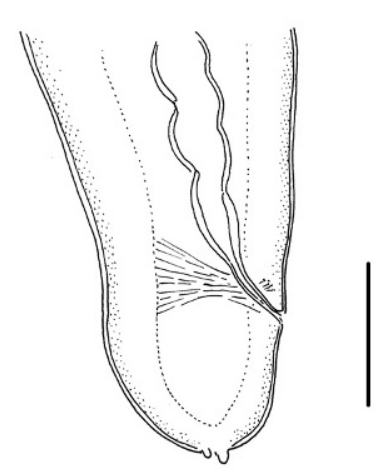

B

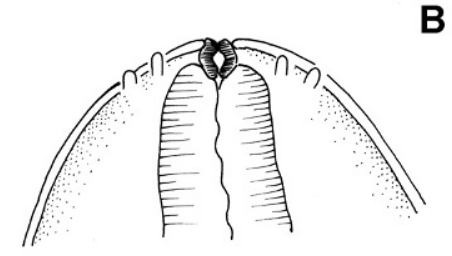

C
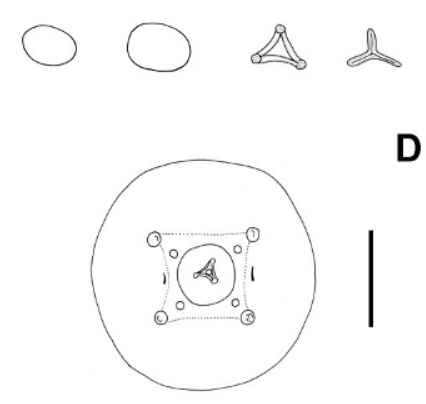

D

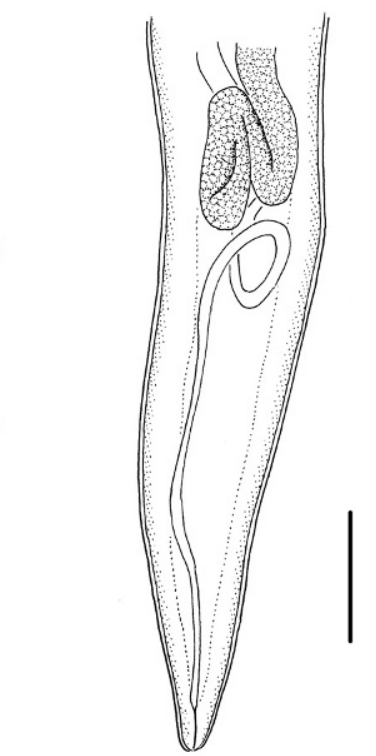

G

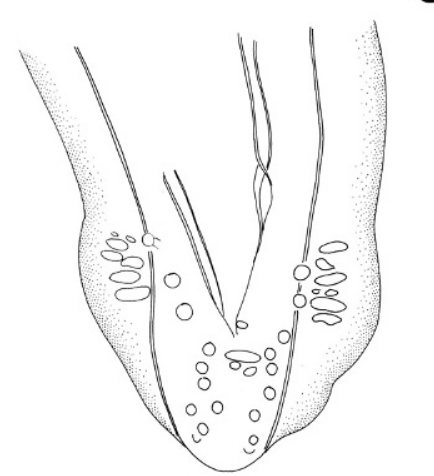

E

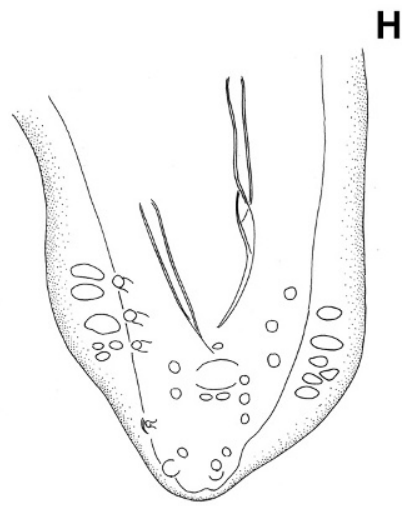

Fig. 2. Adult of Pelecitus tercostatus from Amazona vinacea. A. Female anterior end, showing oesophagus, nerve ring and vulva. B. Female, cephalic extremity detail, showing oral opening and papillae. C. Apical views of oral opening at different levels. D. Apical view, showing cephalic papillae arrangement and amphids. E. Female, posterior end. F. Female, posterior end showing the anus and prominent phasmids. G-H. Male, posterior end showing papillae arrangement. Scale bars (in micrometers): $A=250, B$ and $C=20, D=50, E=500, F=100$, $\mathrm{G}$ and $\mathrm{H}=50$

intermediate hosts (Anderson, 2000). The specificity of this species to psittacids suggest that their intermediate hosts may be chewing lice specific to these hosts, as was recorded for P. fulicaeatrae (Bartlett and Anderson 1987).

The present finding increases the known host and global distribution of P. tercostatus. Amazona vinacea is an endemic parrot from southeaster Brazil and Paraguay and Misiones Province in Argentina. The species has been uplisted to Endangered because the very small populations have suffered a rapid decline owing to extensive habitat loss and fragmentation, compounded by trade, and rapid declines are projected to continue (BirdLife International 2011). This is the first record of any nematode from this native and endemic parrot. Clinically, in the presented case there were no signs of any morbidity. In addition, there was no discomfort or dysfunction displayed by the animal, so the infection was considered to be apathogenic in this particular case. However, although the bird in captivity showed no adverse effects from the infection, the extent of the deformity could have affected its survival if it had been in the wild.

Acknowledgements. The authors gratefully thank Patricia Sarmiento of the SEM service of Museo de La Plata, for her technical assistance and María Cristina Estivariz from CEPAVE for her help with the drawings. We are also grateful to the Conservation Department of the Temaikèn Foundation for the information provided and especially to Bibiana Gomez for her support.

\section{References}

Allen J.L., Kollias G.V., Greiner E.C., Boyce W. 1985. Subcutaneous filariasis (Pelecitus sp.) in a Yellow-Collared Macaw (Ara auricollis). Avian Diseases, 29, 891-894. DOI: 10.2307/ 1590686. 
Anderson R.C. 2000. Nematode Parasites of Vertebrates. Their development and transmission. CABI Publishing, 2nd Edition, $650 \mathrm{pp}$.

Bartlett C.M. 1983. Zoogeography and taxonomy of Dirofilaria scapiceps (Leidy, 1886) and D. uniformis Price, 1957 (Nematoda: Filarioidea) of lagomorphs in North America. $\mathrm{Ca}$ nadian Journal of Zoology, 61, 1011-1022. DOI:10.1139/ z83-135.

Bartlett C.M. 1992. Cold-hardiness in Pelecitus fulicaeatrae (Nematoda: Filarioidea), a parasite of the ankles of Fulica americana (Aves). Journal of Parasitology, 78, 138-139. DOI:10. 2307/3283700.

Bartlett C.M., Anderson R.C. 1987. Pelecitus fulicaeatrae (Nematoda: Filarioidea) of coots (Gruiformes) and grebes (Podicipediformes): skin-inhabiting microfilariae and development in Mallophaga. Canadian Journal of Zoology, 65, 2803-2812. DOI:10.1139/z87-423.

Bartlett C.M., Greiner E.C. 1986. A revision of Pelecitus Railliet and Henry, 1910 (Filarioidea, Dirofilariinae) and evidence for the "capture" by mammals of filarioids from birds. Bulletin $d u$ Museum National d' Histoire Naturelle, Paris, 4th Series, Section A, 47-99.

BirdLife International. 2011. Species factsheet: Amazona vinacea. Downloaded from www.birdlife.org on 10 February 2011.

Escudero G., Diaz J.I., Notarnicola J. 2007. New Host and distribution records of Pelecitus fulicaeatrae (Diesing, 1861) (Nematoda: Onchocercidae). Acta Parasitologica, 52, 419-421. DOI:10.2478/s11686-007-0058-4.
Greiner E.C., Ritchie B.W.1994. Parasites. In: (Eds B.W. Ritchie, G.J. Harrison, L.R. Harrison) Avian Medicine: Principles and Application. Lake Worth, F. L. Wingers Publishing, pp. 1007 $-1029$.

Greve J.H., Graham D.L., Nye R.R. 1982. Tenosynovitis caused by Pelecitus calamiformis (Nematoda: Filarioidea) in the legs of a parrot. Avian Diseases, 26, 431-436. DOI:10.2307/ 1590118

Jimenez-Ruiz F.A., Gardner S.L., Cervantes F.A., Lorenzo C. 2004. A new species of Pelecitus (Filarioidea: Onchocercidae) from the endangered Tehuantepec jackrabbit Lepus flavigularis. Journal of Parasitology, 90, 803-807. DOI:10.1645/GE$213 R 1$.

Oniki Y., Kinsella J.M., Willis E.O. 2002. Pelecitus helicinus Railliet and Henry, 1910 (Filarioidea, Dirofilariinae) and other nematode parasites of Brazilian birds. Memórias do Instituto Oswaldo Cruz, 97, 597-598. DOI:10.1590/S0074-027620020 00400027.

Schuurmans Sterkhoven J.H. 1951. Nematodos parasitarios de anfibios, pájaros y mamíferos de la Republica Argentina. Acta Zoologica Lilloana, 10, 315-400.

Vicente J.J., Rodrigues H.O., Gomes D.C., Pinto R.M. 1995. Nematóides do Brasil. Parte IV: Nematóides de aves. Revista Brasileira de Zoologia, 12, 1-273. 